\title{
ART
}

\section{ИВАН ФРАНКО И УКРАИНСКАЯ МУЗЫКА}

\author{
Профессор, ректор, Заслуженный деятель искусств Украины Юрий Новиков, \\ Украина, Днепр, Днепропетровская академия музыки имени М. Глинки; \\ Кандидат искусствоведения, старший преподаватель Антон Генкин, \\ Украина, Днепр, Днепропетровская академия музыки имени М. Глинки
}

\section{DOI: https://doi.org/10.31435/rsglobal_ws/28022020/6932}

\section{ARTICLE INFO}

Received: 12 December 2019 Accepted: 20 February 2020

Published: 28 February 2020

\section{KEYWORDS}

Ukrainian music, folklore, poetry, national idea, vocal genres, choral music, symphonic music. \begin{abstract}
The article considers the contribution to Ukrainian in the music of the late 19th - early 20th centuries of the poet, public figure, researcher Ivan Franko. Advocating Western Ukrainian folklore, the poet turned to journalism and music criticism. Ukrainian composers created romances, choirs, cantatas, oratorios, vocal-symphonic cantatas, symphonic poems, radio dramas, operas, ballets based on poems by Ivan Frank. The special attention of Ivan Franko to Ukrainian folklore is noted.
\end{abstract}

Citation: Юрий Новиков, Антон Генкин. (2020) Ivan Franko i Ukrainskaya Muzyka. World Science. 2(54), Vol.2. doi: 10.31435/rsglobal_ws/28022020/6932

Copyright: (C) 2020 Юрий Новиков, Антон Генкин. This is an open-access article distributed under the terms of the Creative Commons Attribution License (CC BY). The use, distribution or reproduction in other forums is permitted, provided the original author(s) or licensor are credited and that the original publication in this journal is cited, in accordance with accepted academic practice. No use, distribution or reproduction is permitted which does not comply with these terms.

Введение. В украинскую музыку конца XIX - начала XX века Иван Франко вошел не только как поэт, стихотворения которого стали основой более двухсот вокальных композиций ансамблей, хоров, кантат, ораторий, а некоторые драматические и прозаические произведения преобразовались в либретто балета и опер. Он оставил в ней яркий след как выдающийся общественный деятель. Особенно большое влияние оказал Иван Франко на становление национального демократического направления в музыке Галиции того времени, помог целому ряду молодых западноукраинских композиторов найти путь к реалистическому искусству. Богатство и красота его поэтических образов помогали композиторам более полно раскрыть свою творческую индивидуальность. Великий Каменяр был удивительно разносторонне одаренным человеком, а музыкальным чутьем и феноменальной памятью поражал даже музыкантов. В сборник украинских народных песен Н. Лысенко вошло несколько песен, записанных от Ивана Франко. Очень ценными являются также многочисленные записи народных песен Климента Квитки и Филарета Колессы. «Иван Франко любил народную музыку, песню, - писал композитор С. Людкевич по случаю двадцать пятой годовщины со дня смерти поэта, любил с присущим ему пристрастием. Он не был музыкантам, но умел глубоко почувствовать аромат народной музыки проявляя необычайно тонкое понимание мелодии, умел находить в ней душу» [4].

Результаты исследования. Известно, что собирать поэтический фольклор Иван Франко начал еще в студенческие годы и проводил эту работу на протяжении всей жизни, не оставляя ее даже во время заключения. Созданное им в этой области необычайно велико и ценно. Но заслуга Франко в том, что он выступал зачинателем систематического собирания и публикации музыкального фольклора на Западной Украине. Так, в 1894 году во Львове Иван Франко возглавил комитет, заданием которого были централизация музыкальной фольклористической работы и сплочение энтузиастов вокруг нее. Благодаря ему были опубликованы сборники народных песен Ивана Колессы (1902), И. Роздольского и С. Людкевича (1906), О. Нижанковского. 
«... Когда кто-нибудь говорит, - писал Иван Франко, - что поэту не стоит заниматься пропагандой каких-нибудь идей или идеалов, что общественная борьба, национальные ссоры, те или иные реформы не его дело, то это говорит только его собственное бессилие. Все можно поэту; он человек, и ему надо интересоваться, проникаться всем тем, чем интересуются люди» [9]. И поэт постоянно проявлял интерес к украинской музыке.

Особенно его волновало развитие музыки Галиции. Он не мог примириться с гражданской инертностью некоторых художников, примитивизмом художественной формы. Время от времени поэт обращается к публицистике, к музыкальной критике, хотя сам считал себя дилетантом в этой области. Его труд «Из секретов поэтического творчества» (1898-1899), один из разделов которого посвящен музыкально-эстетическим проблемам, статья «Muzuka polska i ruska» (1892), две полемические статьи, «Праздник Лысенко в Австрии» и «Мысли профана на музыкальные темы» (I905) и рецензии имели большое значение для критической оценки творчества композиторов Галиции.

Много сделал Иван Франко для пропаганды в Галиции произведений Н. Лысенко и особенно его композиций к «Кобзарю», ориентировал западно-украинских композиторов на изучение лучших образцов русской и западноевропейской классики. И тем, что в 90-х годах XIX века на западной Украине выдвинулась плеяда молодых музыкантов, вставших под знамя музыкального реализма, мы в большой мере обязаны влиянию Ивана Франко.

Музыка, написанная на слова Ивана Франко, включает в себя произведения самых разнообразных жанров: от песни до оперы. К числу первых произведений можно отнести музыку В. Матюка к юношеской драме писателя «Три князя на один престол» (музыка не сохранилась). Пропала также и кантата О. Нижанковского «Не гармати грають нині», как, впрочем, и многие другие композиции на тексты Ивана Франко.

Большое значение для освоения украинской музыкой поэтического наследия Ивана Франко имел выход из печати его сборника «Из вершин и низин», ставшего животворным источником для многих композиторов. В поэзии Ивана Франко многие из них находили революционно-освободительную проблематику, задушевную лирику и глубину философских обобщений. М. Коцюбинский писал о том, что Иван Франко - лирик высокой пробы, и его лирические стихотворения просятся часто на музыку. Более всего обращались композиторы к таким сборникам поэта, как «Из вершин и низин» и «Увядшие листья».

Н.В. Лысенко был один из первых, кто обратился к лирике великого Каменяра. Пластичность мелодики, искренность, совершенство формы характеризуют такие романсы как «Місяцю-князю», «Не забудь юних днів», «Оце тая стежечка», «Розвійтеся 3 вітром», проникнутые мечтательной элегичностью.

Значительно субъективнее в выявлении чувств автор предстает перед нами в сборнике «Увядшие листья», что обусловило частое обращение различных музыкантов к отдельным поэзиям этой «лирической драмы» (М. Коцюбинский). Одна из экспозиционных поэзий «Первого клочка», положенных на музыку «Твої очі, як те море» раскрывает лирическую драму двух молодых людей. Она получила несколько интерпретаций в творчестве различных украинских композиторов. Наиболее удачные из них у Б. Лятошинского, Ю. Мейтуса, Ф. Надененко. Если романс Ф. Надененко отличается напевностью, то романс Б. Лятошинского близок своей мечтательностью, а романс Ю. Мейтуса привлекает игрой звуковых красок. Но в раскрытии основного настроения стиха - его поэтичности, вдохновенности - все трое близки между собой. Неизменное внимание музыкантов привлекает стихотворение «Не минай 3 погордою». Психологизм в раскрытии переживания, глубокое проникновение в настроение поэзии свойственны произведениям для голоса Г. Майбороды и Б. Лятошинского. Большую популярность приобрело стихотворение Ивана Франко «Безмежнеє поле», многократно положенное на музыку. Настроение этого стихотворения правдиво отображено в интерпретации Н. Лысенко. Настроение обманутых надежд и присутствие еще живого чувства определяют колорит стиха «Развейтесь с ветром», который Иван Франко назвал эпилогом «Первого клочка».

Если в «Первом клочке» тема любви занимает главное мест, то для второго сборника поэзий любовь представляется недосягаемой мечтой. Одно из лучших стихотворений этого сборника «Ой ти, дівчино, з горіха зерня»", написанного в духе народной песни и проникнутого глубокой нежностью и скорбью, - нашло воплощение в задушевной музыке А. Кос-Анатольского. К стихотворению «Чого являєшся мені» написали музыку Б. Лятошинский, Ф. Надененко и 
К. Данькевич. На слова еще одного стиха - «Як почуєш в ночі» - Я. Лопатинский, Д. Сичинский, Я. Степовой, Г. Майборода. Драма героя здесь раскрыта через напряжение внутренних сил, борьбу чувств. В этих романсах наиболее выявлен драматический конфликт поэзии Ивана Франко.

Многие из стихотворений великого Каменяра стали основой для создания музыки гражданского характера. Это «Кузнец» К. Стеценко, который обнаруживает родство с рабочими песнями «У долині село лежить», «Земле моя» и «Каменярі» Я. Степового. Они сыграли значительную роль в формировании характерных черт гражданской музыкальной лирики. В произведениях А. Штогаренко «Муштруйся, рекруте», Ю. Мейтуса «Гримить» затронуто проблему борьбы за правду и социальное освобождение. Наряду с такими находим и яркие шуточно-сатирические: «Ви чули цю пригоду» А. Штогаренко, написанный в виде народной сцены, «Цехмістер Купер`ян» Ю. Мейтуса.

С именем Ивана Франко связаны и высшие достижения украинской хоровой музыки. К ним относятся хоры С. Людкевича и Н. Лысенко на слова «Вечного революционера». Особенно большую популярность приобрел хор Н. Лысенко. Он звучит как гимн революционному народу. Отсюда высокая обобщенность музыкального языка, синтез характерных интонаций украинских героических песен с интернациональными революционными песнями, героический пафос и мужество выражения. Неоднократно обращались украинские композиторы к стихотворению Ивана Франко «У долині село лежить», относящееся к гражданской лирике поэта. Музыку к нему писали К. Богуславский, В. Борисов, М. Вериковский, Е. Козак, Я. Степовой, Я. Ярославенко. Лучшие образцы претворения лирики философского плана находим в циклах хоров М. Вериковского «Весняна сюїта», Г. Веревки «Три пісні» для хору 3 фортепіано и И. Шамо «Чотири хори на слова Івана Франка». Все три композиции объединяет стремление раскрыть идею произведения через образы природы.

Свободный выбор стихов позволяет каждому из них по-своему раскрыть тему освобождения человека, силы народа, борьбы за братство. Среди лучших лирических и лирико-драматических коппозиций следует назвать произведения Д. Сичинского «Непереглядною юрбою», «Даремне, пісне», а также лирические хоры А. Кос-Анатольского, «Ой жалю мій, жалю» и др., проникнутые глубоким драматизмом, мелодичностью. Образцы кантатно-ораториального жанра в музыкальной франкиане немногочисленны. Наиболее известным произведением является кантата «Еднаймося» К. Стеценко. Вокально-симфоническая кантата «Наймит» С. Людкевича рассказывает о тяжелой судьбе украинского батрака и утверждает неизбежность освобождения и прекрасного будущего. Вокально-симфоническая кантата М. Скорика «Весна», написанная на стихи из цикла «Веснянки» одно из последних произведений этом жанре, связанное с поэзией Ивана Франко.

Из драматических произведений Ивана Франко наибольший интерес вызвало «Украдене щастя». К нему обращались Н. Пруслин, Н. Вериковский, О. Радченко и другие. Известна музыка к радиоинсценицировке сказки Ивана Франко «Фарбований Лис» И. Вымера, а также инсценизации «Каменяров» Л. Ревуцкого. В 1956 году, по случаю 100-летия со дня рождения великого поэта, во Львовском оперном театре была осуществлена постановка балета А. Кос-Анатольского «Сойчине крило». В балете много внимания уделено бытовым моментам, характеристике сценического действия в ущерб раскрытию внутреннего мира героев. Но своей общей направленностью балет утверждает главную гуманистическую идею произведения. На сюжет Ивана Франко написано несколько опер украинских композиторов Б. Лятошинского и Ю. Мейтуса. Опера Б. Лятошинского «Золотой обруч» написана, но мотивам повести «Захар Беркут». Композитор воссоздал в ней картину борьбы тухольцев с татаро-монголами; раскрыты и характеры главных героев. Основная идея произведения - стойкость украинского народа и любовь к родной земле - воплощена убедительно и правдиво. Большую роль играют лейтмотивы, составляющие главный стержень музыкальной ткани оперы и характеристики действующих лиц. Музыкальная ткань богата, колоритна и своеобразна благодаря опоре на народные галицийские песни. Широкое симфоническое развитие придает особую целостность всему произведению.

«Украденное счастье» Ю. Мейтуса - глубокая социально-психологическая драма, необычайно правдива и цельна. Основа музыкального языка оперы - мелодическая декламация, обусловленная преобладанием диалогических сцен. Большое значение имеет оркестровая партия, что позволяет глубже и рельефнее раскрыть характеры главных героев. Яркая национальность, правдивое воплощение основной идеи произведения позволили определить ее как выдающееся достижение украинской оперной музыки. 
Выводы. Образы поэзии Ивана Франко нашли отражение не только в вокальной, но и в симфонической музыке. Эта симфоническая поэма «Не забудь юних днів» С. Людкевича, одноименные симфонические поэмы Г. Майбороды и С. Людкевича «Каменярі». Образ Каменяра нашел отражение в симфонической поэме Л. Колодуба «Великий Каменяр», в хорах А. Кос-Анатольского «Гімн Каменяреві» и 3. Розмарина «Син коваля». Все это свидетельствует о глубокой любви украинского народа к своему великому сыну. Творческое наследие Ивана Франко - неисчерпаемый источник, из которого будут черпать вдохновение украинские композиторы. В различных областях музыки: камерной миниатюре, театральных и монументальных вокально-хоровых композициях - поэтическое слово Иван Франко еще возбудит отклик в сердцах многих художников и зазвучит с новой силой, привлекая сердца к высоким гуманистическим идеалам, которым служил Великий Каменяр.

\section{REFERENCES}

1. Bilecz'ky`j O., Bass I., Ky`sel’ov O. Ivan Franko. Zhy`ttya i tvorchist’. — K., 1956.

2. Gordy`ns' ky’j Ya. Suchasne frankoznavstvo (1916-1932) // ZNTSh. - L., 1935. - T. CLIII.

3. Loshkov Yu. I. Profesijne muzy 'chne my`stecztvo v ponyatijnomu prostori // Kul' tura Ukrayiny': zb. nauk. pr. / Xarkiv. derzh. akad. kul'tury'. Xarkiv, 2008. Vy'p. 22. S. 141-152.

4. Lyudkevich S., Muzyika serdtsa: gaz . Sovetskaya Ukraina, 25 aprelya I94I g.

5. Miroshny'chenko S. V. Kompozy' tors'ky'j profesionalizm yak kategoriya muzy'koznavstva // Ukr. muzy 'koznavstvo. Ky'yiv, 1981. Vy’p. 16. S. 17-31.

6. Mel'ny'chuk B., Uniyat V. Ivan Franko i Ternopil' shhy'na. - Ternopil' : Ternograf, 2012. — $280 \mathrm{~s}$.

7. Moskalenko V. G. Pro rozuminnya muzy'chnogo tvoru // Nauk. visn. Nacz. muz. akad. Ukrayiny` im. P. I. Chajkovs`kogo : zb. st. Ky`yiv, 2002. Vy`p. 20 : Muzy`chny`j tvir: problemy` rozuminnya. S. 3-13.

8. Sy’dorenko G. Literaturno-kry 'ty'chna diyal'nist' Ivana Franka. - K., 1956.

9. Franko I., soch. v 20 tomah,.- Kiev, 1928. t. I6.- s. 250.

10. Franko I.: Zbirny`k / Za zag. red. I. Laky`zy’, P. Fy'ly`povy`cha, P. Ky`yany`ci. — X.: Kny`gospilka, 1926. 